\title{
Gambaran Epidemiologi Perlindungan Spesifik dan Deteksi Dini Anemia Kehamilan Pencegahan Risiko Stunting di Desa Cikunir Kecamatan Singaparna Kabupaten Tasikmalaya
}

\author{
Wuri Ratna Hidayani, Hesti Adzani Ramadhanti, Imelda Sintya \\ STIKes Respati \\ wuri.ratnahidayani@gmail.com
}

\begin{abstract}
Abstrak
Latar Belakang :Berdasarkan survey kepada kader Posyandu di Desa Cikunir menyatakan bahwa masih $70 \%$ yang memahami pentingnya specific protection dan early diagnosis dalam pemeriksaan kehamilan anemia. Tujuan : Untuk mengetahui gambaran epidemiologi perlindungan spesifik dan deteksi dini anemia kehamilan sebagai upaya pencegahan risiko stunting pada balita di Wilayah Kerja Puskesmas Singaparna Kabupaten Tasikmalaya. Metode : Jenis penelitian ini adalah penelitian deskriptif . Populasi penelitian ini semua ibu hamil di Wilayah kerja Puskesmas Singaparna. Sampel penelitian adalah 87 ibu hamil di Desa Cikunir dengan teknik sampling purposive sampling. Instrumen penelitian yang digunakan adalah kuesioner dengan google form dan analisis data menggunakan analisis univariat. Hasil : responden yang mengkonsumsi tablet Fe lebih banyak yaitu 79 responden (90,8\%); menghentikan minum teh dan kopi saat konsumsi Fe yaitu 71 responden $(81,6 \%)$; mengkonsumsi Fe tidak dengan air jeruk 80 orang $(92,0 \%)$ sedangkan dengan air putih 80 orang $(92,0 \%)$, mengkonsumsi Fe ketika letih dan lesu adalah 46 responden $(52,9 \%)$; mengkonsumsi Fe tidak ada efek samping yaitu 80 orang $(92,0 \%)$, konsumsi susu dan biskuit 79 orang $(90,8 \%)$; mengkonsumsi bayam, kangkung, pakcoy, sawi yaitu 60 orang (69,0\%); mengkonsumsi telur, daging ayam, daging sapi, tempe, tahu, ikan memiliki proporsi tertinggi yaitu 80 orang $(92,0 \%)$; kebiasaan mengkonsumsi suplemen beraneka ragam 55 orang $(63,2 \%)$; tempat memeriksakan kehamilan paling banyak ke Bidan Praktek Swasta 49 orang (56,3\%), melakukan pemeriksaan hemoglobin yaitu 63 orang $(72,4 \%)$, responden yang menderita anemia yaitu 7 orang $(8,0 \%)$.
\end{abstract}

Kata Kunci : Perlindungan spesifik, deteksi dini, anemia, kehamilan.

\section{Abstract}

Background: Based on a survey to Posyandu cadres in Cikunir Village, $70 \%$ of them understand the importance of specific protection and early diagnosis in anemia pregnancy checks. Objective: To determine the epidemiological description of specific protection and early detection of anemia in pregnancy as an effort to prevent the risk of stunting in children under five in the Singaparna Health Center, Tasikmalaya Regency. Methods: This type of research is descriptive research. The population of this study were all pregnant women in the working area of the Singaparna Health Center. The research sample was 87 pregnant women in Cikunir Village with purposive sampling technique. The research instrument used was a questionnaire with google form and data analysis using univariate analysis. Results: respondents who consumed more Fe tablets were 79 respondents (90.8\%); stop drinking tea and coffee when consuming Fe, namely 71 respondents (81.6\%); 80 people did not consume Fe with orange juice $(92.0 \%)$ while with water 80 people $(92,0 \%)$, consuming Fe when tired and lethargic were 46 respondents (52.9\%); consuming $\mathrm{Fe}$ had no side effects, namely 80 people (92.0\%), consumption of milk and biscuits 79 people $(90.8 \%)$; consuming spinach, kale, pakcoy, mustard greens, namely 60 people $(69.0 \%)$; consuming eggs, chicken meat, beef, tempeh, tofu, fish has the highest proportion of 80 people (92.0\%); the habit of consuming various supplements 55 people (63.2\%); Most of the places for checking pregnancy are private practice midwives, 49 people (56.3\%), doing hemoglobin checks, namely 63 people $(72.4 \%)$, respondents who suffer from anemia are 7 people (8.0\%).

Keywords : Specific protection, early diagnosis, anemia, pregnancy http://ejournal.urindo.ac.id/index.php/jukmas

Article History :

Submitted 01 September 2021, Accepted 23 Oktober 2021, Published 31 Oktober 2021 


\section{PENDAHULUAN}

Ibu hamil yang kurang memperhatikan perilaku perlindungan khusus salah satunya adalah perilaku memenuhi kebutuhan gizi harian dengan parameter menggunakan piring gizi ibu hamil akan terhindar dari risiko anemia. Kejadian kasus tersebut sangat erat korelasinya dengan etiologi stunting (1).

Anemia merupakan kondisi yang berkaitan dengan ketidakseimbangan antara kepemilikan eritrosit dan persediaan kemampuan distribusi oksigen yang sangat sedikit sehingga tidak mampu mencukupi dan tidak mendukung dalam kinerja organ tubuh yang berdampak negatif pada destruktif sistem sirkulasi (2)

Kejadian hal ini sangat berasosiasi dengan kandungan zat pembentuk darah yang belum memenuhi sesuai kebutuhan yang diperlukan oleh darah. Zat pembentuk darah memiliki peranan yang sangat penting yaitu merupakan alat distribusi berbagai zat nutrisi dan oksigen yang disalurkan ke semua sel jaringan tubuh dengan alternatif dua kondisi yaitu jika kandungan pembentuk darah itu defisit maka tubuh akan mengalami kehilangan nutrisi (3).

Ibu Hamil yang memiliki kandungan zat pembentuk darah dalam tubuhnya dengan sangat defisit akan berasosiasi pada status nutrisi pada anak maupun balita dengan dampak pada kejadian stunting. Hal ini dikarenakan adanya keterhambatan pada perkembangan baik fisik, motorik dan intelegensi pada anak. Anemia merupakan salah satu faktor pemicu yang menjadikan seorang anak dengan kondisi ketidaknormalan dalam tingkat tumbuh kembangnya (4).

Anemia kehamilan merupakan suatu keadaan pada ibu dengan kandungan pembentuk darah pada batasan yang tidak normal yaitu $<11$ gr\% ketika mengandung pada usia 3 bulan, dan 9 bulan sedangkan pada usia kandungan 6 bulan sebesar $<10,5$ gr\%. Anemia kehamilan di sebut "potentional danger to mother and child"(pemicu kerentanan kegawatdaruratan pada ibu dan anak). Oleh sebab itu perlu adanya peningkatan dalam pemberian treatment yang lebih baik terutama fokus sevice dalam mengutamakan mutu maupun kualitas, kuantitas kesehatan bagi ibu dan anak ((5) , (6) .

Epidemiologi anemia terdiri dari host, agent dan environment. Dalam upaya pengendalian anemia dengan cara mengetahui triad epidemiologi dan mengendalikan dari ketiga faktor tersebut (7) . Host anemia adalah manusia, jika anemia kehamilan pada ibu yang hamil. Agent anemia kandungan pembentuk darah pada batasan yang tidak normal yaitu $<11$ gr\% ketika mengandung pada usia 3 bulan, dan 9 bulan sedangkan pada usia kandungan 6 bulan sebesar $<10,5$ gr\% (7)

Environment anemia adalah terdiri dari fisik, biologi, sosial, ekonomi dan budaya. Upaya pengendalian dan pencegahan dengan cara five 
level of prevention salah satunya adalah perlindungan spesifik seperti kebiasaaan ibu hamil dalam konsumsi Tablet Fe, Kebiasaan pola makan gizi seimbang dengan tinggi zat besi, Konsumsi Tablet asam folat, Konsumsi Vitamin B12 dan Vitamin C. Early diagnosis atau deteksi dini yaitu dengan pemeriksaan dini kadar hemoglobin secara berkala ke fasilitas kesehatan selain itu juga adanya screening test anemia (8).

Menurut Hidayani (2021) menyatakan bahwa upaya preventif kasus ini bisa dilakukan dengan berbagai cara antara lain dengan upaya preventif utama dengan cara upaya-upaya kegiatan menyebarluaskan pengetahuan melalui berbagai bentuk media, adanya kegiatan bina suasana anemia, advokasi yang dilakukan dalam rangka memperoleh luaran dari para pemangku kebijakan berupa peraturan yang berisi tentang langkah-langkah kebijakan pengendalian kasus ini. Peran aktif Kader dalam upaya penurunan prevalensi anemia kehamilan antara lain melakukan upaya pendekatan personal maupun kolektif melalui whatsapps group dalam membuka konsultasi bagi ibu hamil. Selain itu dalam upaya preventif primer dengan melakukan berbagai pencegahan perlindungan khusus terutama perilaku ketaatan dalam meminum Fe serta suplemen lainnya dalam upaya preventif kasus ini (8)

Upaya preventif tingkat kedua dengan cara melakukan pendeteksian dini melalui kunjungan rutin ke fasilitas kesehatan. Idealnya seorang ibu hamil melakukan minimal enam kunjungan selama kehamilannya yang biasa dikenal $14 \mathrm{~T}$. Selain itu upaya dalam rangka pembatasan disability salahsatunya dengan cara monitoring dan penilaian dari pengobatan anemia untuk menilai adanya efek samping sehingga dapat menjadi evaluasi dalam langkah treatment berikutnya (7), (8).

Upaya preventif tingkat ketiga adalah segala upaya dalam memproteksi ketika ibu hamil mengalami kegawatdaruratan yang begitu kompleks sehingga melakukan langkah dalam menerapkan agar ibu hamil tersebut memiliki harapan hidup (8). Dalam upaya preventif kasus ini diperlukan kerjasama lintas sektor untuk mengendalikan kasus ini. Upaya preventif ini terutama dalam spesific protection dan early daignosis diperlukan kesadaran ibu hamil dalam menjaga kesehatan selama kehamilan (7).

Anemia kehamilan berdampak negatif bagi kelangsungan calon bayi yang dilahirkan dimasa mendatang salah satunya stunting. Kasus ini perlu dilakukan upaya preventif dalam menurunkan insidensi dan menanggulangi kasus tersebut. Beberapa dampak negatif atau bahaya dari kasus ini antara lain keguguran, kelahiran prematur yang sangat berisiko pada kesehatan bayi yang dilahirkan, proses kelahiran yang terhambat, terjadinya kondisi kontraksi rahim yang terhenti setelah melahirkan yang berakibat pada pendarahan dan kejang. Berdasarkan dampak negatif anemia kehamilan tersebut yang berisiko akan peningkatan mortalitas pada ibu hamil (9) . 
Risiko kegawatdaruratan ini sangat berasosiasi dengan etiologi kasus ini yang berkaitan dengan karakteristik host atau pejamu antara lain kondisi nutrisi, usia, faktor pendapatan keluarga, faktor pengetahuan ibu (9) . Sedangkan bahaya pada janin yang akan antara lain gugurnya janin dalam kandungan, kejadian mortalitas bayi pada saat lahir, bayi lahir secara prematur, kejadian kecacatan genetik (10) .

Menurut Ridayanti (2012) menyatakan bahwa ibu hamil yang baru memiliki anak atau kehamilan pertamanya lebih berisiko terkena anemia kehamilan dibandingkan ibu hamil yang sudah memiliki beberapa anak. Hal ini dikarenakan faktor pengetahuan pada ibu hamil untuk pertama kalinya masih minim sehingga peningkatan risiko anemia kehamilan sangat tinggi (11). Sebaliknya ibu hamil yang sudah beberapa kali mengalami persalinan akan lebih berpengalaman dan memiliki pengetahuan yang cukup dalam perawatan semasa kehamilan (12) .

Dampak anemia kehamilan juga akan menyebabkan stunting pada balita dikarenakan adanya prematuritas, kecacatan pada janin, pertumbuhan dan perkembangan bayi yang lambat (10) .

Berbagai bahaya anemia kehamilan yang sangat berkorelasi antara faktor host dengan environment yaitu faktor sosial budaya dengan salah satunya adalah wawasan ibu hamil akan mempengaruhi dalam perilaku antenatal care dan perilaku konsumsi zat besi atau kepatuhan
Fe, perilaku pemenuhan nutrisi sehari-hari agar kandungannya sehat dan terbebas dari anemia kehamilan. Selain itu faktor lingkungan ekonomi dengan salah satunya pendapatan keluarga yang berasosiasi dengan tingkat kemampuan ibu dalam akses pelayanan kesehatan dan nutrisi ibu (7).

Anemia sangat berdampak negatif pada masa depan balita terutama pada pertumbuhan dan perkembangan balita diantaranya adalah perkembangan intelegensinya terhambat, pertumbuhannya sangat terganggu berbeda dengan balita pada umumnya (8), (9). Tujuan dari penelitian ini untuk mendeskripsikan epidemiologi perlindungan spesifik dan deteksi dini anemia kehamilan sebagai upaya pencegahan risiko stunting pada balita di Desa Cikunir Wilayah Kerja Puskesmas Singaparna Kabupaten Tasikmalaya.

Urgensi riset ini adalah sebagai data epidemiologi yang berguna bagi institusi, stake holder dan masyarakat dalam rangka pencegahan anemia dan pencegahan risiko stunting sehingga adanya peningkatan kesehatan ibu dan anak. Specific Protection terhadap anemia merupakan upaya untuk perlindungan diri bagi ibu hamil dalam mencegah anemia kehamilan.

Urgensi specific protection anemia kehamilan adalah untuk pencegahan dampak negatif anemia terhadap kehamilan yang berisiko terhadap komplikasi kehamilan yaitu keguguran, partus lama, syok pada kehamilan 
serta risiko dalam jangka panjang akan menjadi pemicu stunting pada anak. Early diagnosis pencegahan anemia kehamilan juga sangat penting untuk mendeteksi secara dini anemia pada kehamilan ibu sehingga dapat dicegah sedini mungkin.

Berdasarkan survey kepada kader Posyandu di Desa Cikunir menyatakan bahwa ibu hamil telah memahami pentingnya pemeriksaan berkala dalam pemeriksaan kehamilan dalam pencegahan anemia melalui pendidikan kesehatan, konseling dengan tenaga kesehatan, akan tetapi ibu hamil masih $70 \%$ yang memahami pentingnya specific protection dan earlydiagnosis dalam pemeriksaan kehamilan anemia (9).

\section{World Health Organization (WHO)} menyatakan bahwa anemia pada kehamilan merupakan masalah kesehatan masyarakat dengan trend yang terus meningkat dengan memprediksi sekitar 35\%-75\% pada negara berkembang dan sisanya adalah di negara maju. Menurut laporan WHO bahwa di Asia tenggara menduduki peringkat pertama sekitar 75\%, Mediterania dan Afrika hampir sama yaitu $55 \%$ dan 50\%, sedangkan di bagian Pasifik Barat, Amerika Latin daerah Karibia sekitar 20\%. Wilayah yang memiliki $>10 \%$ telah dinyatakan sebagai daerah zona merah yang harus diwaspadai dikarenakan permasalahan kesehatan (13)

WHO juga menyatakan bahwa etiologi peningkatan mortalitas ibu adalah hampir $50 \%$ yang menimpa pada negara yang masih berkembang, hal ini berkorelasi erat dengan kejadian anemia yang banyak disebabkan oleh aspek perlindungan khusus pada ibu yang belum optimal seperti nutrisi yang belum terpenuhi oleh ibu selama kehamilan juga disebabkan oleh kelalaian dalam akses kesehatan seperti early diagnosis diantaranya rendahnya perilaku ibu dalam pemeriksaan kehamilan (14). Data Kementrian Kesehatan tahun 2017, juga menyajikan bahwa bahwa tingkat kematian ibu terus melonjak dari tahun ke tahun yang sangat erat kaitannya dengan kejadian anemia kehamilan. Tercatat hampir 400 kasus per 100.000 kelahiran hidup (15)

Riset Kesehatan Dasar (Riskesdas) tahun 2018 menyatakan bahwa dari hasil pendataan baik dengan cara kegiatan surveilans aktif maupun surveilans pasif, survey, catatan rekam medik, screening dan pendataan dari berbagai sumber menyatakan bahwa trend kasus anemia selalu meningkat yaitu diketahui angka prevalensinya dari tahun 2013 ke tahun 2018 dengan kenaikan $11,8 \%$. Hal ini tentu menjadi tanggung jawab bersama dalam upaya penurunan kasus ini karena anemia kehamilan merupakan etiologi dalam menyumbang angka kematian Ibu (AKI) dan menjadi penyumbang pada kesehatan anak terutama dampak jangka panjang diantaranya agent pada kejadian stunting balita (16).

Berbagai upaya Pemerintah dalam 
menangani kasus ini terus digalakkan. Berbagai cara juga terus dilakukan untuk meningkatkan kualitas sumber daya manusia dengan peningkatan kesehatan ibu dan anak yang tercermin pada program Pemerintah yang tercantum dalam Progran Kerja Jangka Menengah sampai tahun 2024 salah satunya berkonsentrasi pada program kesehatan ibu dan anak dengan peningkatan nutrisi baik pada anak maupun pada anak yang merupakan calon generasi penerus negeri (17).

Upaya Pemerintah dalam menanggulangi kasus ini adalah denga pendekatan five level of prevention yang salah satunya adalah perlindungan khusus bagi ibu hamil diantaranya dengan pendistribusian Fe bagi ibu hamil dalam memberantas anemia, pendistribusian makanan tambahan bagi ibu hamil. Selain itu juga berbagai upaya penetapan peraturan kebijakan kesehatan yang berorientasi pada fokus penurunan insidensi ini yaitu adanya peraturan pemerintah PMK No 41 Tahun 2014 yang merupakan panduan dalam pemenuhan gizi seimbang bagi ibu hamil dalam preventif anemia. Namun esensi yang harus diperhatikan dalam kebijakan Pemerintah tersebut adalah adanya kesadaran ibu hamil dalam berperilaku sehat selalu aktif berupaya dalam menjaga kesehatan selama kehamilan. Hal ini karena dalam perlindungan spesifik tidak hanya dengan makanan-makanan dengan harga yang mahal tetapi banyak makanan yang mudah terjangkau dengan kandungan gizi yang baik (18).

Menurut profil kesehatan Kabupaten Tasikmalaya tahun 2016 diketahui bahwa capaian konsumsi 90 tablet Fe (besi) oleh ibu hamil mencapai 105\% dari jumlah sasaran 1147 ibu hamil (19) . Hal ini menunjukkan program tablet Fe melebihi target. Akan tetapi masih ditemukan ibu hamil dengan anemia. Kondisi ini bisa terjadi karena Fe tidak dikonsumsi, atau tehnik meminum $\mathrm{Fe}$ yang tidak benar. Berdasarkan hal tersebut maka diperlukan program peningkatan wawasan pada ibu hamil untuk akselerasi wawasan tentang pencegahan anemia dalam kehamilan.

Menurut paparan dari latar belakang diatas peneliti bermaksud untuk melakukan kajian "Gambaran Epidemiologi Perlindungan Spesifik dan Deteksi Dini Anemia Kehamilan Sebagai Upaya Pencegahan Risiko Stunting pada Balita di Desa Cikunir Kecamatan Singaparna Kabupaten Tasikmalaya".

\section{METODE PENELITIAN}

Penelitian ini menggunakan jenis penelitian deskriptif. Populasi penelitian ini semua ibu hamil di Desa Cikunir Kecamatan Singaparna. Sampel penelitian adalah 87 ibu hamil di Desa Cikunir dengan teknik sampling purposive sampling. Kajian riset ini memanfaatkan kuesiner google form sebagai instrumen penelitian yang terdiri dari karakteristik responden dan kuesioner yang 
mencakup variabal penelitian. Waktu penelitian dilakukan pada tanggal 12 Januari s.d 25 Maret 2021.

Tempat penelitian di Desa Cikunir Kecamatan Singaparna Kabupaten Tasikmalaya. Tahapan dalam penelitian ini yang pertama adalah persiapan meliputi antara lain Survei tempat penelitian dan studi pustaka pada penelitian sebelumnya yang ada hubungannya dengan kajian riset ini.

Tahapan berikutnya adalah Penyusunan proposal dan instrumen penelitian (lembar kuesioner), Pengajuan etik penelitian kepada Komisi Etik Penelitian Kesehatan (KEPK) STIKes BTH Tasikmalaya dan telah mendapatkan etichal clearence No.005/kepk-bth/II/2021, pembuatan dan pengajuan perijinan ke Dinas Tasikmalaya, perijinan ke Puskesmas Singaparna dan pengajuan perijinan ke Desa Cikunir.

$$
\begin{aligned}
& \text { Selanjutnya tahap pengumpulan data } \\
& \text { dengan kuesioner google form yang berisi } \\
& \text { identitas responden yang merupakan } \\
& \text { karakteristik responden meliputi usia, usia } \\
& \text { kehamilan, tingkat pendidikan, pekerjaan. } \\
& \text { Variabel independent terdiri dari perilaku } \\
& \text { perlindungan spesifik anemia kehamilan dan } \\
& \text { perilaku deteksi dini anemia kehamilan. } \\
& \text { Perilaku perlindungan spesifik anemia } \\
& \text { kehamilan merupakan perilaku ibu hamil dalam } \\
& \text { upaya pencegahan anemia dalam segi } \\
& \text { perlindungan khusus agar terhindar dari anemia. }
\end{aligned}
$$

Perilaku perlindungan spesifik meliputi kebiasaan konsumsi $\mathrm{Fe}$, menghentikan kopi dan teh selama konsumsi $\mathrm{Fe}$, konsumsi $\mathrm{Fe}$ dan air jeruk, konsumsi Fe dan air putih, konsumsi Fe ketika letih dan lesu, Efek samping minum Fe, konsumsi susu dan biskuit, konsumsi sayuran, konsumsi suplemen, konsumsi protein.

Perilaku deteksi dini anemia kehamilan merupakan perilaku ibu hamil berupa kebiasaankebiasaan dalam mengakses pelayanan kesehatan dalam upaya deteksi dini selama kehamilan. Perilaku deteksi dini anemia kehamilan meliputi tempat pemeriksaan kehamilan, pemeriksaan kadar hemoglobin, status anemia. Sedangkan variable terikat atau dependen adalah anemia kehamilan yang merupakan salah satu faktor risiko stunting pada balita.

Tahap akhir adalah pengolahan hasil, penyusunan laporan, pelaporan dan diseminasi hasil penelitian. Analisis data dengan menggunakan analisis univariat yang mendeskripsikan karakteristik responden dan variabel penelitian. 


\section{HASIL DAN PEMBAHASAN}

A. Hasil

1. Karakteristik Responden

Pada kajian riset ini karakteristik responden berdasarkan usia dapat diketahui bahwa bahwa responden berumur 29-31 tahun memiliki proporsi paling banyak $(20,7 \%)$, responden yang memiliki jumlah anak 1 anak memiliki proporsi paling banyak sebanyak 50 responden $(63,2 \%)$, responden dengan kehamilan ke 2 memiliki proporsi paling banyak sebanyak 36 responden $(41,4 \%)$.

Responden dengan usia kehamilan Trimester III memiliki proporsi paling banyak sebanyak 37 responden (42,2\%). Berdasarkan pendidikan didapatkan hasil bahwa responden dengan pendidikan SMA memiliki proporsi paling banyak sebanyak 32 responden $(36,8 \%)$ sedangkan berdaasarkan pekerjaan yaitu IRT memiliki proporsi paling banyak sebanyak 74 responden $(85,1 \%)$.
2. Analisis Univariat Gambaran Epidemiologi Perlindungan SpesifikAnemia Kehamilan Berdasarkan hasil kuesioner dengan google form, maka analisis univariat berdasarkan perilaku perlindungan spesifik anemia kehamilan dapat diketahui pada Tabel 1. 
Jurnal Untuk Masyarakat Sehat (JUKMAS)

Tabel 1. Distribusi Frekuensi Responden berdasarkan Perilaku Perlindungan Spesifik Anemia Kehamilan

\begin{tabular}{llrr}
\hline No & Variabel Perilaku Perlindungan Spesifik Anemia Kehamilan & Frekuensi & Persentase (\%) \\
\hline $\mathbf{1}$ & Kebiasaan Konsumsi Fe & 79 & \\
& Ya & 80,8 \\
& Tidak & 8 & 9,2
\end{tabular}

2 Menghentikan kopi dan teh selama konsumsi Fe

Ya

Tidak

$3 \quad$ Konsumsi Fe dan air jeruk

Ya

Tidak

$4 \quad$ Konsumsi Fe dan air putih

Ya

Tidak

$5 \quad$ Konsumsi Fe ketika letih dan lesu

Ya

Tidak

6 Efek samping minum Fe

Ya, susah buang air besar

Ya, Tinja Berwarna Hitam

Tidak

7 Konsumsi Susu dan Biskuit

Ya

Tidak

8 Konsumsi sayuran

1 jenis sayuran

Berbagai jenis sayuran (bayam, kangkung, pakcoy, sawi) 
Hanya 1 jenis suplemen

Beraneka ragam (Asam Folat, Yodium, VitaminB12,Vitamin C)

10 Konsumsi Protein

Hanya 1 jenis protein

Beraneka ragam jenis (telur, daging ayam, daging sapi, tempe,

80

92,0 tahu, ikan)

\section{Jumlah}

87

100,0

3. Analisis Univariat Gambaran Epidemiologi Deteksi Dini Anemia Kehamilan Berdasarkan hasil kuesioner dengan google form, maka analisis univariat berdasarkan perilaku deteksi dini anemia kehamilan dapat diketahui pada Tabel 2.2.

Tabel 2 . Distribusi Frekuensi Responden berdasarkan Perilaku Deteksi Dini Anemia Kehamilan

\begin{tabular}{llrr}
\hline No & Deteksi Dini dan Status Anemia & Frekuensi & Persentase (\%) \\
\hline $\mathbf{1}$ & $\begin{array}{l}\text { Tempat Pemeriksaan Kehamilan } \\
\text { Puskesmas }\end{array}$ & 19 & 21,8 \\
& Bidan Praktik swasta & 49 & 56,3 \\
& Rumah Sakit, Dokter SpOG & 6 & 6,9 \\
Bidan Praktik Swasta, Dokter SpOG & 8 & 9,2 \\
Puskesmas, Rumah Sakit, Dokter SpOG & 1 & 1,1 \\
Lainnya, Pustu & 4 & 4,6
\end{tabular}

2 Pemeriksaan Kadar Hemoglobin

Ya

Tidak

3 Status Anemia

Ya

Tidak

Ya

$\begin{array}{ccc} & 7 & 8,0 \\ & 80 & 92,0 \\ \text { Jumlah } & 87 & 100,0\end{array}$

B. Pembahasan

Penelitian ini menggunakan rancangan deskriptif dengan 87 sampel ibu hamil. Penelitian ini bertujuan untuk mendeskripsikan perlindungan spesifik dan deteksi dini anemia kehamilan dalam upaya pencegahan stunting pada balita di Desa Cikunir, Kecamatan
Singaparna Kabupaten Tasikmalaya. Analisis yang digunakan adalah analisis univariat.

1. Karakteristik Responden

Proporsi tertinggi pada umur responden adalah berumur 29-31 tahun $(20,7 \%)$. Menurut Rezeki (2014) pada 
penelitian karakteristik ibu, konsumsi tablet Fe dengan kejadian anemia di Kabupaten Kendal dengan pendekatan crossectional menyatakan bahwa responden sebagian besar berada pada usia produktif yaitu 20-35 tahun dengan rerata usia 28 tahun (20). Umur merupakan salah satu faktor yang mempengaruhi host (pejamu) anemia kehamilan. Golongan usia 29- 31 merupakan kelompok umur yang termasuk usia dewasa sehingga dapat menentukan dalam upaya perlindungan spesifik dan dapat bertindak dalam deteksi dini anemia kehamilan dalam upaya pencegahan stunting balita yang merupakan dampak jangka panjang anemia kehamilan (21) .

Responden dengan usia kehamilan Trimester III memiliki proporsi paling banyak sebanyak 37 responden (42,2\%). Faktor ini merupakan tergolong faktor host yang merupakan risiko anemia kehamilan, ketika ibu memiliki pengetahuan dan kesadaran yang baik untuk senantiasa berperilaku sehat khususnya dalam upaya perlindungan spesifik dengan pola makan yang sehat dan deteksi dini yang baik dengan rutin memeriksakan status anemia dapat menekan risiko anemia meskipun trimester III sangat rentan dalam risiko anemia.

\footnotetext{
Berdasarkan

pendidikan

didapatkan hasil bahwa responden
}

dengan pendidikan SMA memiliki proporsi paling banyak sebanyak 32 responden (36,8\%). Menurut Fajrin (2020) dalam penelitian anemia kehamilan di Kabupaten Lamongan dengan pendekatan crossectional menyatakan bahwa karakteristik responden berdasarkan pendidikan adalah SMA yaitu sebanyak 12 orang (62,3\%). Tingkat pendidikan ibu dengan pendidikan menengah merupakan berkaitan dengan faktor pengetahuan ibu tentang cara perlindungan diri terhadap anemia dengan pola hidup yang sehat serta patuh pada anjuran tenaga kesehatan dalam pencegahan anemia kehamilan(22).

Berdasarkan pekerjaan yaitu IRT memiliki proporsi paling banyak sebanyak 74 responden $(85,1 \%)$. Pekerjaan sebagai Ibu Rumah Tangga (IRT) jika tidak aktif dalam pencarian informasi dalam pencegahan anemia kehamilan terutama dalam specific protection dan early diagnosis maka akan berisiko dalam kejadian anemia kehamilan yang memicu akibat dimasa yang akan datang adalah stunting pada balita. Tetapi jika profesi sebagai ibu rumah tangga senantiasa aktif dalam pencarian informasi maka akan mengetahui tentang cara pencegahan anemia kehamilan terutama dalam perlindungan spesifik dan deteksi dini anemia kehamilan sehingga diharapkan dapat meningkatkan derajat kesehatan 


\section{Jurnal Untuk Masyarakat Sehat (JUKMAS)}

ibu dan anak dengan melahirkan generasi yang sehat dan bebas dari stunting.

\section{Gambaran Epidemiologi Perlindungan} Spesifik Anemia Kehamilan sebagai Upaya Pencegahan Stunting pada Balita

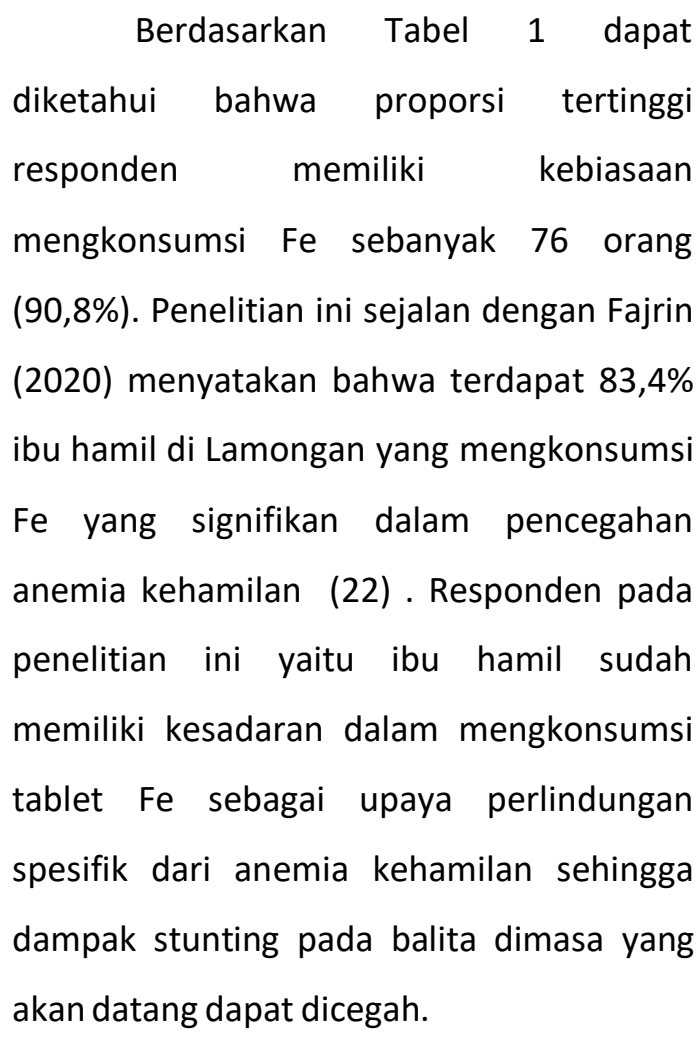

$$
\text { Responden paling banyak }
$$
menghentikan kopi dan teh selama konsumsi Fe sebanyak 71 orang $(81,6 \%)$. Hal ini menunjukkan bahwa konsumsi tablet Fe yang disertai dengan minum teh dan kopi akan memperlambat absorbsi zat besi karena mengandung senyawa tanin dalam minuman teh dan kopi tersebut (23). Kebiasaan mengkonsumsi Fe tidak dengan air jeruk sebanyak 80 orang $(92,0 \%)$. Sedangkan responden mengkonsumsi $\mathrm{Fe}$ dengan air putih adalah 80 orang $(92,0 \%)$. Menurut Rusmiati (2019) menyatakan bahwa adanya perbedaan antara konsumsi Fe tanpa Vitamin C dan setelah menggunakan bersamaan dengan vitamin $\mathrm{C}$ yaitu pada hasil penelitiannya sebelum mengkonsumsi $\mathrm{Fe}$ bersamaan dengan vitamin $\mathrm{C}$ responden memiliki kadar $\mathrm{Hb}$ sebesar 10,7 gr\%, sedangkan setelah vitamin $\mathrm{C}$ dikonsumsi bersamaan dengan $\mathrm{Fe}$ adanya kenaikan $\mathrm{Hb}$ yaitu sebesar $12,7 \mathrm{gr} \%$ (24) .

Responden yang mengkonsumsi $\mathrm{Fe}$ tidak ada efek samping memiliki proporsi tertinggi yaitu 80 orang $(92,0 \%)$ dibandingkan dengan responden yang menyatakan ada efek samping tinja berwarna hitam yaitu 2 orang (2,3\%). Berdasarkan penelitian Hayati (2020) menyatakan bahwa efek dari tablet $\mathrm{Fe}$ diketahui bahwa sebanyak 25 responden $(38,5 \%)$ mengalami konstipasi dan 40 responden (61,5\%) tidak mengalami konstipasi (25) .

Berdasarkan penelitian melalui kuesioner dengan google form dapat diketahui bahwa responden dengan kebiasaan mengkonsumsi susu dan biskuit ibu hamil yaitu 79 orang (90,8\%). Berdasarkan Kemenkes (2018) menyatakan bahwa penyebab stunting dibedakan menjadi 2 yaitu penyebab langsung dan tidak langsung adalah kurangnya ketersediaan makanan yang kaya kandungan nutrisi, pengasuhan yang kurang optimal, akses ke fasilitas kesehatan 


\section{Jurnal Untuk Masyarakat Sehat (JUKMAS)}

juga memiliki dampak pada stunting balita. Ada korelasi antara rendahnya pendapatan dengan pemenuhan kebutuhan keluarga termasuk dalam hal kebutuhan pangan dan sarana sanitasi lingkungan. Kebutuhan pangan erat kaitan dengan pemenuhan gizi ibu hamil karena masalah gizi ibu dan balita merupakan agent atau penyebab stunting dimasa mendatang (26) .

Menurut hasil penelitian diketahui bahwa proporsi tertinggi responden dalam konsumsi sayuran adalah mengkonsumsi beraneka ragam sayuran adalah 60 orang $(69,0 \%)$. Ibu hamil sebaiknya mengupayakan dalam memenuhi nutrisi selama kehamilannya. Untuk memudahkan ibu hamil dalam pemenuhan nutrisi sebaiknya memanfaatkan berbagai media yang menginformasikan cara memenuhi nutrisi. Hal ini merupakan upaya perlindungan diri terhadap anemia. Berbagai sayuran yang dapat dikonsumsi antara lain sayuran hijau yang kaya akan kandungan zat besi. Selain itu penting diperhatikan dalam tata cara pengolahan sayuran hijau agar tidak terdegradasi kandungan zat besi yang aada pada sayuran tersebut (27) .

Responden dengan kebiasaan
mengkonsumsi berbagai jenis suplemen
yaitu asam folat, vitamin C, vitamin B 12,
$\begin{array}{lll}\text { yodium sebanyak } 55 \text { orang }(63,2 \%) \text {. } \\ \text { Menurut Darwanty } & \text { (2012) bahwa } \\ \text { prosentase ibu hamil dengan kadar asam }\end{array}$

folat rendah sebanyak $70 \%$ dan penderita anemia sebanyak $30 \%(28)$. Oleh karena itu konsumsi suplemen pada saat hamil merupakan upaya perlindungan diri ibu hamil yang sangat urgent bagi kesehatan ibu dan janin yang dikandung dalam menekan prevalensi anemia kehamilan yang berkorelasi dengan stunting pada balita di masa mendatang.

$$
\text { Responden yang memiliki }
$$
kebiasaan mengkonsumsi beraneka ragam makanan yang mengandung protein memiliki proporsi tertinggi yaitu sebanyak 80 orang $(92,0 \%)$. Pola makan yang sehat bagi ibu hamil merupakan upaya pencegahan perlindungan spesifik yang dapat menurunkan keterpaparan dalam anemia kehamilan yang berpotensi pada kejadian stunting balita. Dalam pemenuhan nutrisi ibu hamil harus memenuhi jumlah porsi yang dianjurkan sesuai dengan pola gizi seimbang yang terukur dalam isi piringku ibu hamil dengan proporsi sesuai takaran yang telah ditentukan sehingga makanan yang dikonsumsi dapat terabsorbsi dengan sempurna (29) .

\section{Gambaran Epidemiologi Deteksi Dini} Anemia Kehamilan sebagai Upaya Pencegahan Stunting pada Balita

Berdasarkan hasil penelitian berdasarkan kuesioner dengan google form dapat diketahui bahwa responden yang memilih tempat pemeriksaan 


\section{Jurnal Untuk Masyarakat Sehat (JUKMAS)}

kehamilan di Bidan Praktik Swasta memiliki proporsi tertinggi sebanyak 49 orang (56,3\%), sedangkan proporsi terendah adalah responden yang memilih Puskesmas, Rumah Sakit, Dokter SpOG sebanyak 1 orang $(1,1 \%)$. Selain itu responden melakukan pemeriksaan hemoglobin lebih banyak yaitu 63 orang $(72,4 \%)$ daripada responden yang tidak memeriksakan kadar hemoglobin yaitu 24 orang (27,6\%). Menurut Penelitian Abidah (2019) menyatakan bahwa hampir seluruh responden yaitu $92 \%$ melakukan pemeriksaan kehamilan tidak rutin $(<4$ kali) mengalami anemia dibandingkan responden yang rutin melakukan pemeriksaan kehamilan ( $\geq 4$ kali) tidak mengalami anemia kehamilan (30) . Oleh karena itu upaya deteksi dini ibu hamil sangat penting dengan cara rutin melakukan kunjungan ke fasilitas kesehatan dan rutin dalam pemeriksaan kehamilan juga status kesehatan seperti pemeriksaan hemoglobin sehingga adanya kontrol kesehatan ibu hamil.

Mayoritas responden adalah yag tidak terpapar anemia 80 orang $(92,0 \%)$ dibandingkan dengan yang terpapar anemia yaitu 7 orang (8,0\%). Berbeda dengan penelitian Astapani (2020) menyatakan bahwa status anemia pada ibu hamil lebih banyak yang terpapar anemia yaitu 64 orang $(64,6 \%)$, sedangkan responden yang tidak anemia sebanyak 35 orang $(35,4 \%)(30)$. Dampak anemia bagi ibu pada saat kehamilan diantaranya pendarahan pasca melahirkan, kejang, melahirkan dengan durasi lama, kondisi rahim tidak bisa berkontraksi setelah melahirkan sehingga pendarahan yang hebat, persalinan dengan durasi lama yang berdampak kematian,sisanya karena etiologi lain, sedangkan dampak anemia pada bayi baru dilahirkan diantaranya BBLR, kelainan bawaan, dampak jangka panjang kegagalan dalam perkembangan balita yang memicu pada gangguan kerusakan fungsi fisiologi organ tubuh salah satunya berakibat stunting (31) .

\section{KESIMPULAN}

Berdasarkan hasil penelitian pada $87 \mathrm{ibu}$ hamil dengan pemanfaatan google form dapat disimpulkan bahwa gambaran epidemiologi perlindungan spesifik antara responden yang mengkonsumsi tablet Fe lebih banyak yaitu 79 responden $(90,8 \%)$; menghentikan minum teh dan kopi saat konsumsi Fe yaitu 71 responden $(81,6 \%)$; mengkonsumsi Fe tidak dengan air jeruk 7 orang $(8,0 \%)$ sedangkan dengan air putih 80 orang $(92,0 \%)$, mengkonsumsi Fe ketika letih dan lesu adalah 46 responden (52,9\%); mengkonsumsi Fe tidak ada efek samping yaitu 80 orang $(92,0 \%)$, konsumsi susu dan biscuit 79 orang $(90,8 \%)$; mengkonsumsi bayam, kangkung, pakcoy, 
sawi yaitu 60 orang ( 69,0\%); mengkonsumsi Telur, daging ayam, daging sapi, tempe, tahu, ikan memiliki proporsi tertinggi yaitu 80 orang $(92,0 \%)$; kebiasaan mengkonsumsi suplemen beraneka ragam 55 orang (63,2\%); tempat memeriksakan kehamilan paling banyak ke bidan praktek swasta 49 orang (56,3\%), melakukan pemeriksaan hemoglobin yaitu 63 orang $(72,4 \%)$, responden yang menderita anemia yaitu 7 orang $(8,0 \%)$.

\section{UCAPAN TERIMA KASIH}

Riset ini tidak terlepas dari berbagai pihak khususnya kontribusi STIKes Respati, Tasikmalaya atas pendanaan dalam riset ini. Selain itu apresiasi kepada ibu hamil di Desa Cikunir Kecamatan Singaparna, Tasikmalaya yang telah berdedikasi dalam keikutsertaan dalam riset ini.

\section{DAFTAR PUSTAKA}

(1) Mann Jim; Truswell, Stewart. Buku Ajar IImu Gizi Edisi 4. Jakarta: EGC, 2014

(2) WHO. Global Prevalence of Anemia in 2011. Department of Nutrition for Health and Development World Health Organization. Geneva, Switzerland,2011.

(3) Apriningtyas, V.N; Kristini, T.D. Faktor Prenatal yang Berhubungan deYogyakartangan Kejadian Stunting Anak Usia 6-24 bulan. The Indonesian Journal Public Health. Volume 14, Nomor
2, November 2019, 2019, p 13-17. Available

https://jurnalunimus.ac.id/indexphp/jkmi diakses pada 10 Agustus 2021

(4) Iftikhar, A.,Bari, A., Zeeshan, F., Jabeen, U., Masood, Q., Waheed, A .Maternal Anemia and its Impact on Nutritional Status of Children Under The Age of Two Years, $5 \quad(3), 2018$, 4-7. https://doi.org/10.26717/BJSTR.2018.05. $\underline{001197}$

(5) Bobak, Lowdermilk, Jensen. Keperawatan Maternitas. Jakarta :EGC,2005

(6) Manuaba. Ilmu Kebidanan, Penyakit Kandungan dan KB untuk Pendidikan Bidan. Jakarta:EGC,2010

(7) Hidayani, WR. Epidemiologi. Yogyakarta: Deepublish,2020

(8) Hidayani, WR. Pencegahan Anemia Kehamilan di Era Pandemi COVID-19 (Pendekatan Early Diagnosis Anemia Kehamilan dan Dampak Terhadap Stunting Balita). Yogyakarta:CV Markumi, 2021

(9) Prawirodihardjo, Sarwono. IImu Kebidanan. Cetakan Keempat. Jakarta : Yayasan Bina Pustaka Sarwono Prawirohardjo,2005

(10) Melku M, Assis Z, Aleem M, \& Enawgaw B. Prevalence and Preditors of Maternal Anemia During Pregnancy in Gondar, 


\section{Jurnal Untuk Masyarakat Sehat (JUKMAS)}

Northwest Ethiopia: An Institutional Based Crossectional Study. Hindawi Publishing Corporation, 2014.

(11) Ridayanti. Hubungan tingkat Pendidikan Ibu Hamil dengan Kejadian Anemia Pada Kehamilan di Puskesmas Banguntapan I Bantul. Yogyakarta :UMY,2012

(12) Farsi, Y., Brooks, D., Werler, M., Cabral, H., Al Syafei, M\&Wallenburg, H.C. Effect of High Parity on Occurance of Anemia in Pregnancy : a Cohort Study. BMC Pregnancy and Chilbirth,2011; 11(7), 7

(13) World Health Organization (WHO).The Global Prevalence of anaemi in 2011. Geneva World Health Organization, 2015

(14) Aminin,Fidyah, Atika Wulandari, Ria Pratidina Lestari. Pengaruh Kekurangan Energi Kronis (KEK) Dengan Kejadian Anemia Pada Ibu Hamil, Jurnal Kesehatan, 2014, 5 (2): 167-72

(15) Kementerian Kesehatan Republik Indonesia (Kemenkes RI). Profil Kesehatan Indonesia 2017.Data dan Informasi. Kementerian Kesehatan RI, 2018

(16) Depkes RI. Hasil Riset Kesehatan Dasar (Riskesdas) Tahun 2018. Kementerian Kesehatan Republik Indonesia, p 1-100

(17) Sari, dr. Mayang, Victorino, Wariaseno,IP, Latuconsina, AS, Astuti. Indikator Program Kesehatan Masyarakat Dalam
RPJMN dan Rentra Kementerian Kesehatan 2020-2024, 2020, p 1-99

(18) Permenkes No. 41 Tahun 2014. Gizi Sembang,2014.https://peraturan.bpk.go.i d diakses pada 10 Agustus 2021

(19) Profil Kesehatan Kabupaten Tasikmalaya. Dinas Kesehatan Kabupaten Tasikmalaya,2016

(20) Rezeki, S; Huda, A. Karakteristik Ibu, Konsumsi Tablet Fe Dengan Kejadian Anemia Pada Kehamilan Di Wilayah Kerja Puskesmas Kaliwungu Kabupaten Kendal;2014

(21) Kementrian Kesehatan RI.Profil Kesehatan Indonesia 2014. Jakarta,2014

(22) Fajrin, Fl. Kepatuhan Konsumsi Zat Besi (Fe) terhadap Kejadian Anemia Pada Ibu Hamil.Jurnal Kesehatan Vol 3 No. 4 Oktober,2020,p336-342 https://jurnal.fkmumi.ac.id diakses tanggal 20 Agustus 2021

(23) Septiawan. Hubungan Kebiasaan Minum The Dengan Kejadian Anemia Pada Ibu Hamil Trimester li. Lampung, Volume Vi, No.2, Oktober 2015

[24) Rusmiati, D. Pengaruh Pemberian Suplemen Zat Besi dengan dan tanpa Vitamin C Terhadap Kenaikan Kadar Hemoglobin Ibu Hamil. Jurnal IImiah Bidan Vol IV No. 2, 2019 


\section{Jurnal Untuk Masyarakat Sehat (JUKMAS)}

(25) Hayati, Susani. Pengaruh Konsumsi Tablet Fe Dengan Kejadian Konstipasi Pada Ibu Hamil Di Puskesmas Payung Sekaki Pekanbaru. Jurnal Medika Husada Vol 3 Nomor 1, Februari 2020

(26) Pusdatin Kemenkes, R. I. Situasi Balita Pendek (Stunting) di Indonesia. Buletin Jendela Data dan Informasi Kesehatan. Pusat Data dan Informasi, Kementerian, Kesehatan RI,2018

(27) Padmiari Ida Ayu Eka. Manfaat Buahbuahan dan Sayur-sayuran Politek,nik Kesehatan Depkes RI. Denpasar,2010

(28) Darwanty, J. Hubungan Konsumsi Fe Terhadap Kejadian Anemia Pada Ibu Hamil di Kabupaten Karawang Tahun 2014. Jurnal Kebidanan, Vol 7, No.1 (2018) Hal 14-22.
(29) Kementrian Kesehatan RI. PMK No.41 tentang Pedoman Gizi Seimbang, 2004

(30) Abidah S.N. Analisis Faktor-Faktor Yang Berhubungan Dengan Kejadian Anemia Pada Ibu Hamil Trimester III Di BPM Kusmawati Surabaya Jurnal Ilmiah Kesehatan (Journal of Health Sciences), Vol. 12, No. 2, Agustus 2019, Hal. 99-108

(31) Putra O, Pengaruh BBLR Terhadap Kejadian Stunting pada Anak Usia 12-60 bulandi Wilayah Kerja Puskesmas Pauh Pada Tahun 2015. Universitas Andalas, 2016 